\title{
The situation of women in the labor market in Poland in the light of existing labor law provisions concerning the working time
}

\begin{abstract}
Increasing the share of women on the labour market is an urgent issue that Europe must face in the context of aging society, which is perceived as a threat for the future socio-economic situation of European countries. However, in 2012 women's participation in the labour market of the European Union was even by $12.2 \%$ lower than that of men. Poland was among the few countries with the greatest difference in the share of sexes on the labour market. One reason for women's lower professional activity is the difficulties in combining work with family responsibilities. For many women maternity means long-term unemployment, or even resignation from a professional career, in relation to difficulties with returning to the labour market. Labour law may have a positive or negative impact on the situation of women on the labour market. An important regulation in this regard is one that regulates working time. Based on the analysis of the applicable regulations from the Labour Code, the article focuses on the available ways of working time management by the employee in the context of possible combining of work and the fulfilment of family responsibilities.
\end{abstract}

Key words: labour law, working time, work-life balance

\section{Introduction}

ncreasing the share of women on the labour market is an urgent issue that Europe must face in the context of aging society, which is perceived as a threat for the future socioeconomic situation of European countries. Data of the European Commission and Eurostat show that the society of all the 28 European Union countries is aging, and this process is bound to aggravate in the next years (European Comission, 2013). If the current demographic tendency continues, according to forecasts by 2050 the number of people aged 65 or above will have grown by approx. $70 \%$, and the working-age population (15-64) will have been reduced by $12 \%$ (Eurostat, 2008). Against the background of other countries, Poland is experiencing the aging of the society at a greater and greater pace (Żołędowski, 2012, pp. 38-39). It is forecast that in the years 2010-2035 the number of people aged 65 or above will increase from $13.5 \%$ to $23.2 \%$ (GUS, 2009, pp. 181-187). Statistically, women live longer than men. As found in twelve member states, including Poland, women's average life span was twice as long as men's (Eurostat, 2012a). In these conditions, increasing the number of professionally active people, especially women, has been identified as one of the instruments used to counteract the phenomenon of aging society and to achieve goals defined in the Europe 2020 Strategy. ${ }^{1}$

Still, in 2012 women's participation in the labour market of the European Union $(62.4 \%)$ was even by $12.2 \%$ lower than that of men (74.6\%). Poland was among the few

${ }^{1}$ Europe 2020 - European strategy for smart, sustainable and inclusive growth, http://ec.europa. eu/eu2020/pdf/1_PL_ACT_part1_v1.pdf, 16.09.20115. 
countries with the greatest difference in the share of sexes on the labour market, which was $57.5 \%$ for women and $72 \%$ for men (European Comission, p. 1). It is underscored that women are more exposed to unfavourable situations on the labour market (e.g. because they more often have fixed-term employment contracts, have to work part time, receive lower remunerations, or are long-term unemployed), and in the long run, also to poverty. ${ }^{2}$ In 2012 in Poland, only 55.8\% women had full-time employment, whereas in the case of men, it was $72.4 \%$ (European Comission, p. 9).

One reason for women's lower professional activity is the difficulties in combining work with family responsibilities, especially parenting. Eurostat data clearly show that parenting has a negative influence on women's employment ratio nearly in all the member states (European Comission, p. 2). This is connected on the one hand with the traditional role division in the family between a man and a woman, and on the other hand with the rigid labour law regulations and insufficiently developed system of childcare services. As a result, for many women maternity means long-term unemployment, or even resignation from a professional career, in relation to difficulties with returning to the labour market. Labour law, which is an instrument of labour market regulation, may have a positive or negative impact on the situation of women on the labour market. The basic act regulating employment relationship in Poland - the Labour Code - includes legal regulations which may affect women's access to the labour law in terms of possible combining of work and family responsibilities. An important regulation in this regard is one that regulates working time. Based on the analysis of the applicable regulations from the Labour Code, the article focuses on the available ways of working time management by the employee in the context of possible combining of work and the fulfilment of family responsibilities.

\section{Towards greater working time flexibility and better work-life balance of an employee}

Working time remains one of the key issues in the ongoing debate over the way to achieve the better balance between professional and private life of an employee (worklife balance strategy). ${ }^{3}$ Working time flexibility, which allows parties to the employment relationship to adjust the working time to their individual needs, has been indicated as one of the instruments of the work-life balance strategy (Beauregad, 2009, pp. 9-22). Flexibility can refer both to the volume of work and to scheduling the working hours

${ }^{2}$ In 2007 at-risk-of-poverty rates among women stood at 17\%, while among men it stood at $15 \%$. The highest gap in at-risk-of-poverty was among elderly (22\% for women and $17 \%$ for men) - see Sprawozdanie Komisji dla rady, Parlamentu Europejskiego, Europejskiego Komitetu EkonomicznoSpołecznego i Komitetu Regionów. Równość kobiet i mężczyzn - rok 2010, KOM(2009) 694 wersja ostateczna, http://analizy.mpips.gov.pl/images/stories/publ_i_raporty/Raport_rownosc_plci_w_ UE_2010_25-01-10.pdf, 18.10.2015.

${ }^{3}$ See M. Tausing, M. Fenwick, Unbinding time: Alternate work schedules and work-life balance, "Journal of Family and Economy", Issues 2001, no. 2, s. 101-119; J. Tomlison, Employment regulation, welfare and gender regimes: a comparative analysis of women's working-time patterns and work-life balance in the UK and US, "The International Journal of Human Resource" 2007, no. 3, s. 401-415; D. M. Houston, Work-life balance in the 21st century, Palgrave Macmillan, London 2005. 
(Plantega, Remery, 2010). It is suggested that women more often than men associate the flexibility of working time with work-life balance improvement, and therefore women more frequently request for flexible working arrangements with reference to their working time (Shagvaliyeva, Yazdanifard, 2014, p. 2). The form of working time flexibility dominant among women all over Europe, resulting from the necessity to combine professional work with family responsibilities, is part-time work. However, although it leads to an increased employment rate among women, at the same time it often suppresses their career progression as women usually work below their skills then (Eurofund, 2012). It is because part-time work, unlike full-time work, is mostly possible in elementary occupations (Silim, Stirling, 2014, p. 23). It is therefore essential to promote another forms of working time flexibility that put more emphasis on scheduling their working time without the need to reducing it.

Work-life balance strategy has recently become a priority of the European Union (EU) policy. European Commission refers directly to work-life balance strategy and the consequent necessity to promote greater working time flexibility, with regard to the demographic challenges related to the ageing of the European society, in the resolution on the renewal of EU directive 2003/88/EC concerning certain aspects of the organisation of working time. ${ }^{4}$ Including in the directive 2003/88/EC principle of adapting work to the worker only refers to the "humanisation of work" - ensuring safe and healthy working conditions, as an overriding objective of the directive, indicated in article $1 \S 1$ (Rayer, 2012, p. 4). The lack of any provisions on work-life balance in the current directive 2008/88/EC creates a serious challenge. The EU Commission therefore emphasized that while maintaining the fundamental aim of the directive - ensuring safe and healthy working conditions - at the same time "consideration should be given to including in the directive protective measures such as: encouragement for social partners to conclude, at the appropriate level and without prejudice to their autonomy, agreements aimed at supporting reconciliation of work and family life; the right to information well in advance of any substantial change to the pattern of work; an 'obligation to examine workers' requests for changes to their working hours and patterns, in the light of each other's needs for flexibility, and to give reasons if refusing such requests" (European Comission, 2010, p. 12).

\section{Regulation of working time in the Polish Labour Code - the attempt to achieve a balance between working time flexibility and security of the employee}

Regulation of working time are constituted of the manifestations of the protective function of labour law, which is considered to be the backbone of the labour law. The protective function of labour law is based on the idea of balance between the positions

${ }^{4}$ Directive 2003/88/EC of the European Parliament and of the Council of 4 November 2003 concerning certain aspects of the organisation of working time (EU Official Journal L 299 from 18.11.2003, p. 9). See European Commission, Communication from the Commission to the European Parliament, the Council, The European and Social Committee and the Committee of the Regions Reviewing the Working Time Directive (second-chase consultation of the social partners at European level under article 154 TFUE), \{SEC(2010) 1610 final $\}.$ 
of the parties to the employment relationship by granting employees the rights which they would not be given as part of individual negotiation of working conditions with the employer (Kahn-Freund, 1979, p. 7; Skapski, 2006). Regulation of working time is essential to ensure decent and fair working conditions, the health care of employees, as well as to facilitate a better combination of work with the employee's private life, which is especially the role of the right to the maximum number of hours of work and the minimum rest period, both of which have been considered by the Court of Justice of the European Union (CJEU) as a principle of EU social law with a particular gravity. ${ }^{5}$ At the same time, however, regulation of working time is strongly susceptible to civilisation and socio-economic changes, as shown by the example of consecutive amendments to regulation of working time in Polish Labour Code, especially those after 1996 (Sobczyk, 2005). At the time of current cultural, social and economic changes, it is reasonable to talk about flexibility as a dimension in the development of the regulation of working time (Sobczyk, 2005). Not only the economic interest of the employer but also the interest of the employee, which is expressed in the possibility to adjust their working time to non-business activities, especially families responsibilities, lies behind the move towards greater flexibility in working time regulations. It is surely necessary to agree that both the right to rest and safe and health working conditions constitute the limits to the flexibility of working time regulations (Sobczyk, 2005).

Among the forms of flexibility of working time regulated by the Polish legislation we can distinguish those which are related, on the one hand, to the length of working time, and on the other, to the organisation of working time. The first group includes part time work, overtime and work on Sundays or public holidays, while in the second group there are different systems of working time based on standards of working time and the combination of reference periods.

From the point of view of the position of women on the labour market and the possibility to combine their professional and private life, working time flexibility belonging to the second group seems to be significant, especially the system of performance working time, the system of shortened working day, the system of weekend working time, individual work schedule and so-called flexible working time, which may constitute an alternative for part time work, which is the form of working time flexibility dominant among women in Poland. Amendments of 14 November $2003^{6}$ and of 6 December $2008^{7}$ have given additional maternity leave to employees (Article $181^{1} \S 5$ and 6 of the Polish Labour Code), additional leave equivalent to maternity leave (Article $183 \S 4$ of the Polish Labour Code) and parental leave (Article $186^{7}$ of the Polish Labour Code), the right to request the reduction of working time, no more than half, in order to work in this period at the employer that grants this leave. With regard to additional maternity leave and additional leave equivalent to maternity leave, the acceptance of employee request is relatively obligatory, while the employer may reject it indicating that it is contrary to

${ }^{5}$ See the ruling of CJUE of 26 June 2001 in the case C-173/99, BECTU, ECR [2001] I-4881; the ruling of CJUE of 18 March 2004 in the case C-342/01 Merino Gomez, ECR [2004] I-2605.

${ }^{6}$ Act on Amending the Labour Code and certain other acts of 14 November 2003, (Journal of Laws from 2003, No. 213, item 2081).

7 Act on Amending the Labour Code and certain other acts of 6 December 2008, (Journal of Laws from 2008, No 237, item 1654). 
the organisation of work or the type of work of the employee. Although, with regard to parental leave, the employee's request is absolutely obligatory for the employer. In general, the above amendments must be welcomed, as they allow employees, especially women, to remain on the labour market in the period of the above-mentioned leave. At the same time, however, it causes the risk of remaining in part time work also after those leaves, when the employee would be deprived of the possibility to enjoy those forms of working time flexibility which allow the employee to manage their working time within full time employment.

\section{System and schedule of working time - scheduling of working time for better adjustment of work and family responsibilities}

The system and schedule of working time, as well as the rules for fixing them, are essential for employees to manage their working time. The system of working time, which indicates "permissible length of working time and the rules for its fixing in the day and week within a particular reference period" (Góral, Stefański, 2013), is established by the standards of working time, rest periods and reference period. An employee may manage their working time within their schedule of working time established under a particular system of working time (Nałęcz, 1997, p. 111).

The primary working time system was a starting point for other systems of working time. In the primary working time system the day working time standard has been determined at a fixed level of 8 hours. The weekly working time standard has been fixed at average level, relating to the adopted reference period and accrued average 40 hours per average week of five working days, but no more than 48 hours per week. ${ }^{8}$ The working time standards correspond with minimum daily and weekly rest periods. ${ }^{9}$ The law granted an employee the right to at least 11 hours of continuous daily rest ${ }^{10}$ and at least 35 hours of continuous weekly rest, with consideration of overtime.

The amendment of 12 July $2013^{11}$ introduced the possibility to extend in every system of working time the reference period up to 12 , if it is justified with broadly defined objective, technical or organisational reasons. The essence of the reference period in working time flexibility was recognized by the Supreme Court in the ruling of 11 March 2010, which emphasized that "the essence of the reference period of working time leads to the conclusion that within a given reference period the number of working days shall be determined first and on that basis the number of overtime hours resulting from ex-

8 The specific provisions may differently determine the working time standards. For instance with regard to young employee (article $202 \S 1$ of the Polish Labour Code), disabled person with high or intermediate level of disability (article 15(2) Vocational Rehabilitation and Employment of Disabled Persons Act of 27 August 1997, Journal of Laws from 2011, No. 127, item 721 as amendment).

${ }^{9}$ In the ruling of 10 March 2011 the Supreme Court has determined that employee may not waive his right to rest (III PK 50/10, Lex no. 901624).

${ }_{10}$ The definition of working day has been included in article 128 of the Polish Labour Code as a subsequent 24 hours, since the hour in which the employee starts his work due to his schedule of working time.

${ }_{11}$ Act on Amending Labour Code and Act on trade unions of 12 July 2013 (Journal of Laws from 2013, No. 186) - hereinafter as a Act of 12 July 2013. 
ceeding average-weekly standards of working time, which have not been compensated for by time off work and therefore are subject to the remuneration that includes ordinary wage and an appropriate wage supplement. The balance of the employee's working time shall be made after the end of a reference period. Then the employee receives the right to claim the payment of remuneration for overtime work in this period" (I PK 191/09, OSNP 2011/17-18/228).

However, unless the length of the reference period is relevant to the application of weekly working time standard, the 8-hours day working time standard is still a major obstacle in flexible organisation of working time (Rycak, 2009). Work carried out above the daily working time standard constitutes overtime, with all its consequences, especially with a prohibition on overtime for pregnant women and the necessity to receive a permission for overtime from an employee who is caring for a child under 4 (Article 178 of the Polish Labour Code). The working time standards laid down in the law express "normal and medically and socially acceptable workload of a particular employee" (Pisarczyk, 2011). In this regard, the Polish legislator goes far beyond the protective measures adopted in directive 2003/88/EC, which do not include the notion of working day and in which working time is only restricted to the maximum average 48-hours weekly working time standard, minimum 11-hours continuous daily rest period and minimum 24-hours weekly rest period.

The other systems of working time, which include: the equivalent system of working time (Article 135-137 of the Polish Labour Code), performance system of working time (Article 140 of the Polish Labour Code), interrupted system of working time (Article 139 of the Polish Labour Code), working time in continuous motion (Article 138 of the Polish Labour Code), shortened week working time system (Article 143 of the Polish Labour Code), weekend working time system (Article 144 of the Polish Labour Code) and shortened working time system (Article 145 of the Polish Labour Code) constitute an exception from the primary working time system. In majority, the implementation of such systems of working time will be imposed because of the needs of employer related to the type of work and/or organisation of work (interrupted and equivalent system of working time as well as working time in continuous motion) or may result from specific working conditions (shortened working time). However, from the employee's perspective, performance working time system, shortened week working time system and weekend working time seem to be important, as their interests involve the necessity to adjust work to family responsibilities. In the performance system of working time, it is determined by the tasks of the employee. According to Article 140 of the Polish Labour Code, the introduction of the performance system of working time my justified by the type of work, its organisation or place. The performance system of working time may therefore be desired in telework, especially when the work can be provided from home. In the performance system of working time the employee manages their working time independently, organising their work in a way which in their opinion allows them to perform their tasks within the period of time stipulated by the employer. Due to the risk of working longer than working time standards, the law provides that the working time of an employee should be stipulated by the employee in such a way as to allow the employee to perform their tasks within working time standards. The law therefore provides for the employer's duty to collaborate with the employee in this regard. In the 
event of a dispute between the parties to the employment relationship, the employer is required to prove that the tasks given to the employee could have been performed in the working time within the working time standards under Article 129 of the Polish Labour Code. ${ }^{12}$

Contrary to the performance system of working time, the shortened week working time system and weekend working time system are relatively new institutions, as they both were introduced to the Polish Labour Code through the Amendment of 14 November 2003 due to the struggle for further flexibilisation of the labour law. ${ }^{13}$ The condition for introducing the shortened week working time system is the employee's request, reflecting the fact that in the clear intention of the legislator these systems should only be determined by the individual interest of an employee. It follows from the lack of possibility of the employer modifying the employee's will in this regard, although negotiation between parties to the employment relationship is not excluded (Góral, Stefański, 2008). In the shortened week working time system it is possible to extend daily working time standard up to 12 hours with work performed for less than 5 days a week in the reference period nor exceeding one month. At the same time, it is assumed that the standard of maximum 4 days each week represents a hard target, which cannot be exceeded (Sobczyk, 2005). In the weekend working time system, in which work is performed only on Fridays, Saturdays, Sundays and public holidays, it is also possible to extend the daily working time standard up to 12 hours in the reference period not exceeding one month. The introduction of the above system of working time allows for the performance of work on Sunday irrespective of the type of work (Article $151^{10}(10)$ of the Polish Labour Code). Moreover, the employer is not required to grant such an employee a day off work in return for Sunday work (Article $151^{11}$ of the Polish Labour Code) or to guarantee the employee at least every fourth Sunday free (Article $151^{11}$ of the Polish Labour Code). It has to be emphasized that in both systems the extension of daily 8 hours working time standard in the case of an employee caring for a child under 4 is dependent on their consent (Article 148 of the Polish Labour Code). With regard to this category of employees, the above regulation has a relative protective character. This allows for preserving the flexibility of those institutions, when due to the interest of a particular employee it is justified to introduce such an organisation of their working time in which it is allowed to exceed the daily working time standard, assuming that the introduction of one or both of the above working time systems has also been based on the will of the employee. In addition in both working time systems it is possible to extend the reference period subject to general conditions due to the above-mentioned Article $129 \S 2$ of the Polish Labour Code.

The above-mentioned Amendment of 14 November 2003 introduced to the Labour Code the institution of individual schedule of working time, provided for in Article 142 of the Polish Labour Code. In this way, only at the written request on the employee is it possible to introduce an individual schedule of their working time within their working time system. Under the individual schedule of working time it is possible to indicate

12 The ruling of Supreme Court of 15 March 2006, II PK 165/05, OSNP 2007, no. 5-6, item 69.

13 See justification to the draft to the Act on Amending the Labour Code and certain other acts, http://orka.sejm.gov.pl/Druki4ka.nsf/\%28\$vAllByUnid\%29/2C5F50B0FEEEA959C1256C850057A9 AA/\$file/1162.PDF, 17.10.2015, p. 8. 
week's working days, the organisation of working time on particular working days, the start time and end time on particular working days, as well as intervals at work (Raczka, 2004, p. 30). In 2013, the legislator went one step beyond, when he introduced to the Labour Code the institution of a variable working time schedule. ${ }^{14}$ In the legislator's intention the adopted amendments were to introduce a more flexible organisation of working time, the purpose of which was among others to allow employees, especially women, to more easily combine their professional and private lives..$^{15}$ The institution of a variable working time schedule may significantly contribute to the equalization of the chances of women on the labour market and to facilitating their return to the labour market following the birth of a child. The adopted legal regulations remain almost entirely repetitions of the legal regulation that was included in the previous Act of 1 July 2009 on Mitigation of Economic Crisis Effects for Employees and Entrepreneurs ${ }^{16}{ }^{16}$ which for the first time provides for the possibility of introducing a variable working time schedule. However, these two regulations were based on different assumptions. The above-mentioned Act was a part of the so-called anti-crisis package, which was aimed at helping companies that faced financial difficulties due to the ongoing economic crisis (Rosa, 2011). According to Article $140^{1}$ of the Polish Labour Code, the variable working time schedule may occur in two variations. Firstly, it may provide for different start and end times on particular working days $(\S 1)$. Secondly, it may provide for a period of time in which the employee decides on the start time of the working day $(\S 2)$. It is also possible to simultaneously apply to the employee the above forms of variable working time schedule (Kaleta, 2013). In this way the legislator just sanctioned the current practice based on the provisions on individual working time schedule. ${ }^{17}$ However, contrary to the individual working time schedule, the importance of the institution of variable working time schedule consists in the fact that in both of its variations involve the re-performance of work by employee within the subsequent 24 hours (within the same working day) does not constitute overtime, which allows employee more flexible management of their working time (§ 4). It has to be emphasized that the second form of the variable working time schedule, included in $\S 2$ of Article $140^{1}$ of the Polish Labour Code, allows to better adjust working time to the employee's private activities, especially family responsibilities, particularly when the employee has a possibility to decide to start the working day within the period of time provided by the employer (Ludera-Ruszel, 2014, p. 19). Contrary to individual working time schedule, the variable working time schedule may also be introduced on the employer's initiative.

The provision of the Polish Labour Code concerning the rules on the introduction of systems and schedules of working time significantly limit the managerial power of the employer with regard to the organisation of work (Article $22 \S 1$ of the Polish Labour

${ }_{14}$ Act on Amending Labour Code and Act on trade unions of 12 July 2013 (Journal of Laws from 2013, No. 186).

15 Justification to the draft to the Act on Amending Labour Code and Act on trade unions, www. orka.sejm.gov.pl/Druki7ka.nsf/0/1D507853B1A4DA52C1257B170039FF66/\%24File/1105.pdf, 09.10.2015, p. 1 .

16 Journal of Laws from 2009, No. 125, item 1035 - hereinafter as a act on mitigation on economic crisis.

17 See the opinion of the Main Labour Inspectorate, GNP-302-45601115/05/PE, "Rzeczpospolita" of 10 January 2007 , df 7. 
Code) (Pisarczyk, 2011). In this regard the law provides trade unions with the right to negotiate those issues in a collective agreement. The primacy of collective agreement with regard to systems and schedule of working time clearly follows from Article $151 \S 1$ of the Polish Labour Code. Both work regulation and the announcement of the employer may replace the collective agreement only when there is no trade union in the company or if a collective agreement has not been concluded. However, when with regard to work regulation Article $104^{2} \S 2$ of the Polish Labour Code provides for the participation of trade union in determination of its contents, there is no such duty with regard to the contents of the announcement of the employer, which does not constitute a source of labour law but is a unilateral act of managerial power of the employer (Dubownik, 2004, p. 8). Neither work regulation nor the announcement of employer may, however, replace a collective agreement or an agreement concluded with representatives of the employee with regard to the extension of the reference period, due to Article $129 \S 2$ of the Polish Labour Code and the introduction of variable working time schedule, which further restricts the power of the employer in this regard (Article $150 \S 3$ of the Polish Labour Code). The above-mentioned rules apply to the introduction of systems and schedule of working time at the company level, which means with regard to the whole staff or particular employees.

On the other hand, an individual employment contract may modify the above regulations concerning working time,$^{18}$ for example through the introduction of performance working time (Stanibuła, 2005, p. 26), which in every singular cases would require evaluation taking into account the principle of performance of the employee, derived from Article $18 \S 1$ of the Polish Labour Code.

An employment contract constitutes the only possible form for the introduction of shortened week system of working time and weekend system of working time that results from the individual nature of those systems, which may only be applied on the request of employee.

Less formalised is the way of introduction of an individual working time schedule and a variable working time schedule, both of which are only based on the request of the employee. The application of those schedules of working time at the request of the employee is possible regardless of its introduction at the company level, due to Article 150 $\S 1$ of the Polish Labour Code, which allows to take into account the needs of particular employees in this regard.

It has to be noted that the request of an employee to introduce a shortened week working time system, weekend working time system or individual and variable working time schedule is not binding for the employer (Kaleta, 2013). The law does not put on the employer the duty to accept the employee's request in this regard, and does not specify a number of conditions for the right of refusal. In this way an employee does not acquire the claims to its introduction (the right to request flexible working time), which would be the subject of judicial review, which therefore significantly impairs the effectiveness of those institutions of working time with regard to the implementation of work-life balance strategy, which in practice are within the sole discretion of the employer.

\footnotetext{
${ }_{18}$ See ruling of Supreme Court of 17 July 2009, I BP 6/09, Lex no. 523547.
} 


\section{Conclusion}

It follows from the above considerations that the regulation of working time is one of the key instruments of the implementation of work-life balance strategy, which is aimed at achieving a balance between the professional and private life of an employee. Regulation of working time that allows to adjust the working time of an employee to their family responsibilities may have a positive impact on greater participation of women on the labour market, which is crucial with regard to the ageing population. In this regard we can observe progressive flexibility of working time regulations included in Polish Labour Code, which put more emphasis on the scheduling of working time within full time employment without the need to its reduction. However, part-time work, which currently is the form of working time flexibility predominant among women, leads to increased suppression of their career progression and as a result to the greater risk of poverty and social exclusion among women.

The main obstacle to the introduction of forms of flexible organisation of working time by an employee is a lack of employee's right to adjust their working time to their family responsibilities without the need to reduce working hours or resign from the employment. Under the existing law the introduction of flexible working hours is generally dependent only on the sole discretion of the employee, which significantly weakens the effectiveness of those institutions, in the light of the goals which inspired its introduction to the regulation of labour law. The introduction of the right to reduce working hours for employees during the additional maternity leave and childcare leave was a significant step in this direction. In the light of implementation of the protective function of labour law it would be reasonable for the legislator to follow this direction and put on employers the general obligation to examine workers' requests for flexible working hours, which is not limited to employees that make use of the above mentioned leaves and reduction of working time, and to give reasons if refusing such requests that would be subject to judicial review.

\section{Bibliography}

Beauregad T. A. (2009), Making the link between work-life balance practices and organizational performance, "Human Resource Management Review", vol. 19.

Dubownik A. (2004), Regulaminy pracy po nowelizacji kodeksu pracy. Sytuacja pracodawców niezobowiqzanych do ustalania regulaminów, „Praca i Zabezpieczenie Społeczne”, no. 3.

Eurofound (2012), Fifth European Working Conditions Survey, Publications Office of the European Union, http://eurofound.europa.eu/publications/report/2013/other/working-time-and-worklifebalance-in-a-life-course-perspective, 16.10.2015.

European Comission (2013), EU Employment and Social Security. Quarterly Review. Special Supplement on Demographic Trends, Eurostat, European Commission, Luxembourg, www.ec.europa. eu, 06.10.2015.

European Comission, Female labour market participation, p.1, http://ec.europa.eu/europe2020/pdf/ themes/31_labour_market_participation_of_women.pdf, 18.10.2015.

European Commission (2010), Communication from the Commission to the European Parliament, the Council, The European and Social Committee and the Committee of the Regions Reviewing the Working Time Directive (second-chase consultation of the social partners at European level under article 154 TFUE), \{SEC(2010) 1610 final\}. 
Eurostat (2008), Ageing characterises the demographic perspectives of the European societies, Eurostat, Statistic in focus 72, http://epp.eurostat.ec.europa.eu/cache/ITY_OFFPUB/KS-SF-08-072/ EN/KS-SF-08-072-EN.PDF, 13.10.2015.

Eurostat (2012a), Aktywność osób starszych i solidarność międzypokoleniowa. Statystyczny portret Unii Europejskiej, Eurostat Statistical books, table 1.1, p. 18, http://analizy.mpips.gov.pl/images/stories/publ_i_raporty/ER2012/final_statystyczny_portret_UE_pl.pdf, 10.12.2015.

Góral Z. (ed.), Stefański K. (2008), Czas pracy, Lex 2013, Lex/el., in:, M. B. Rycak, Wymiar i rozkład czasu pracy, Warszawa.

GUS (2009), Prognoza ludności na lata 2008-2035, Główny Urząd Statystyczny, Warszawa, http:// www.stat.gov.pl/cps/rde/xbcr/gus/L_prognoza_ludnosci_na_lata2008_2035.pdf, 14.10.2015.

Kahn-Freund O. (1979), Arbeit und Recht, Band Verlag.

Kaleta J. (2013), Jak wprowadzić ruchomy czas pracy-poradnik krok po kroku, Lex Omega/el.

Ludera-Ruszel A. (2014), Ruchomy czas pracy - szansa czy zagrożenie dla pracowników, „Monitor Prawa Pracy 2014".

Nałęcz A. (1997), Czas pracy, Gdańsk.

Pisarczyk Ł. (2011), in: Kodeks pracy. Komentarz, ed. L. Florek, Lex/el.

Plantega J., Remery C. (2010), Flexible working time arrangements and gender equality. A comparative review of 30 European countries, European Union, http://ec.europa.eu/social/main.jsp?cat $\mathrm{Id}=738 \&$ langId $=$ en\&pubId=585\&type $=2 \&$ furtherPubs $=$ no, 15.10 .2015 .

Rayer C. (2012), The review of the EU Working Time Directive - mediating flexibility and security: the dialogue of the European legislator, the ECJ and social partners, http://repository.ubn.ru.nl/ bitstream/handle/2066/91426/91426.pdf? sequence=1, 12.10.2015.

Rączka K. (2004), Ustalanie systemów i rozkładu czasu pracy na gruncie kodeksu pracy, „Praca i Zabezpieczenie Społeczne", no. 4.

Rosa A. (2011), Pakiet antykryzysowy - zmiany dla pracodawców, ABC, Lex Omega/el.

Rycak M. B. (2009), Planowanie i rozliczanie czasu pracy, ABC, Lex/el.

Shagvaliyeva S., Yazdanifard R. (2014), Impact of Flexible Working Hours on Work-Life Balance, "American Journal of Industrial and Business Management", vol. 4, p. 2.

Silim A., Stirling A. (2014), Report. Women and flexible working. Improving female employment outcomes in Europe, Institute for Public Policy Research, p. 23.

Skapski M. (2006), Ochronna funkcja prawa pracy w społecznej gospodarce rynkowej, Kraków, Lex/el.

Sobczyk A. (2005), Zasady prawnej regulacji czasu pracy, ABC, Lex/el.

Stanibuła B. (2005), Ewolucja zasad stosowania zadaniowego czasu pracy, „Praca i Zabezpieczenie Społeczne", no. 8.

Żołędowski C. (2012), Starzenie się ludności - Polska na tle Unii Europejskiej, „Problemy polityki społecznej. Studia i Dyskusje", vol. 17.

\section{Sytuacja kobiet w runku pracy w Polsce w świetle obowiązujących regulacji prawa pracy dotyczących czasu pracy}

\section{Streszczenie}

Zwiększenie udziału kobiet na rynku pracy pozostaje pilną kwestią, z jaką zmierzyć się musi Europa w kontekście zjawiska starzenia się społeczeństwa, które jest postrzegane w kategoriach zagrożenia dla sytuacji społeczno-gospodarczej państw europejskich. Tymczasem w 2012 r. stopień partycypacji kobiet na rynku pracy był aż o 12,2\% mniejszy od mężczyzn. Polska znalazła się w grupie państw o największej różnicy w udziale między kobietami a mężczyznami na rynku pracy. Jedną z przyczyn niższej 
aktywności zawodowej kobiet są trudności w łączeniu pracy zawodowej z obowiązkami rodzinnymi. Dla kobiet macierzyństwo oznacza długotrwałe bezrobocie, a nawet rezygnację z pracy zawodowej, w przypadku trudności z powrotem na rynek pracy. Prawo pracy może wpływać pozytywnie bądź negatywnie na sytuację kobiet na rynku pracy. W tym zakresie istotne znaczenie mają przepisy dotyczące czasu pracy. W oparciu o analizę obowiązujących regulacji Kodeksu pracy z zakresu czasu pracy podjęte rozważania koncentrują się na dostępnych sposobach zarządzania czasem pracy przez pracownika w kontekście możliwości łączenia pracy zawodowej z realizacją obowiązków rodzinnych.

Słowa kluczowe: prawo pracy, czas pracy, równowaga pomiędzy życiem zawodowym a osobistym 